\title{
Human Papillomavirus Research on the Prevention, Diagnosis, and Prognosis of Cervical Cancer in Taiwan
}

\author{
Angel Chao, MD, PhD; Huei-Jean Huang, MD; Chyong-Huey Lai, MD
}

Cervical cancer is third in incidence and fourth in mortality among cancers of women worldwide. Epidemiological studies have shown that human papillomavirus (HPV) is necessary, if not sufficient, to cause nearly $100 \%$ of cervical cancers. HPV testing is useful in primary screening for cervical neoplasms. The value of HPV detection or genotyping is potentially useful in triage of borderline or low-grade abnormal cervical cytology, follow-up after treatment of cervical intraepithelial neoplasia, assessment of prognosis and treatment planning for invasive cervical cancer. Studies from Chang Gung Memorial Hospital have defined the genotype distribution of cervical cancer in Taiwan and confirmed the independent prognostic value of the HPV genotype in cervical cancer. The cost-effectiveness of using HPV testing in prevention and management

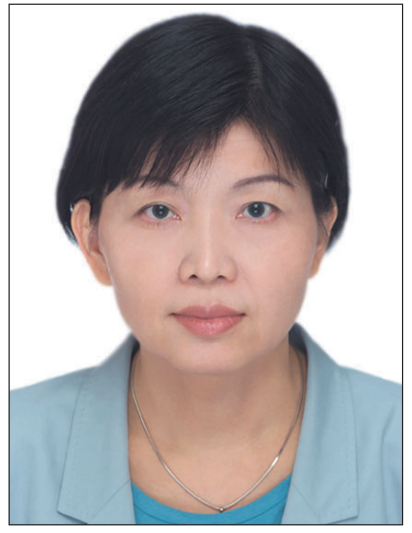

Prof. Chyong-Huey Lai of cervical neoplasms depends on the medical and public health infrastructure of the individual country. The population-based HPV prevalence and genotype distribution as well as longitudinal follow-up studies have established strong support for incorporating HPV testing with cervical cytology and for future comparisons of HPV epidemiology before and after implementation of HPV prophylactic vaccines in Taiwan. Future directions in HPV research are discussed. (Chang Gung Med J 2012;35: 297-308)

Key words: cervical neoplasm, human papillomavirus, cancer screening, prognosis

$\mathrm{C}$ ervical cancer is third in incidence and fourth in mortality among cancers of women worldwide. ${ }^{(1)}$ zur Hausen first suggested that human papillomavirus (HPV) was likely to be a sexually transmitted agent in the mid-1970s. ${ }^{(2)}$ More recent molecular and epidemiological studies have shown that HPV is the main causative agent of cervical neoplasms. HPV contributes to the development of cervical intraepithelial neoplasia (CIN) and subsequent invasive car- cinomas. ${ }^{(3)}$ To date, approximately 120 different HPV types that infect humans have been indentified. The 15 leading HPV types (HPV16, 18, 58, 33, 52, 39, $45,31,51,56,59,35,68,73$, and 82) that have been linked to cervical cancer constitute high-risk types. ${ }^{(4)}$ Characterization of the HPV types according to phylogenetic species resulted in their assignment to the following groups: $\alpha 1 / \alpha 8 / \alpha 10$ (HPV6, $11,40,32,42$, 43, 44, 55, and 74), $\alpha 3 / \alpha 15$ (HPV61, 62, 71, 72, 81,

\footnotetext{
From the Department of Obstetrics and Gynecology, Chang Gung Memorial Hospital at Linkou, Chang Gung University College of Medicine, Taoyuan, Taiwan.

Received: July 19, 2011; Accepted: Dec. 28, 2011

Correspondence to: Prof. Chyong-Huey Lai, Department of Obstetrics and Gynecology, Chang Gung Memorial Hospital at Linkou. 5, Fusing St., Gueishan Township, Taoyuan County 333, Taiwan (R.O.C.) Tel: 886-3-3281200 ext. 8254; Fax: 886-3-3288252;

E-mail: sh46erry@ms6.hinet.net
} 
83, and 84), $\alpha 5 / \alpha 6$ (HPV26, 51, 53, 56, 66, 69, and 82), $\alpha 7$ (HPV18, 39, 45, 59, 68, and 70), and $\alpha 9$ (HPV16, 31, 33, 35, 52, 58, and 67). ${ }^{(5)}$ Although the rate of cervical cancer has declined since 1960, this disease is still a major burden in the Asia-Pacific region. ${ }^{(6)}$ According to statistics from the Department of Health of Taiwan, the incidence of cervical cancer was $12.2 / 100,000$ in $2007 .{ }^{(7)}$ Research on the role of HPV in cervical cancer is active in Taiwan. The purpose of this review is to summarize the literature on methods of HPV detection and genotyping, HPV molecular epidemiology in cervical neoplasms, the roles of HPV testing in diagnosis and management of CIN, HPV genotypes in the prognosis for cervical cancer, and perspectives on HPV vaccines with emphasis on the most significant findings of those from Taiwan.

\section{Diagnostic efficacy of HPV detection}

Over recent decades, many studies worldwide have attempted to identify specific HPV DNA types. ${ }^{(4)}$ Initially, Southern blot analysis was the gold standard for HPV DNA analysis. However, this technique is specific but laborious, and its sensitivity is low. A commercial kit called the Vira Pap/ Vira Type kit, which involves the use of the dot blot test based on radiolabeling, was developed. In 1993, the presence of HPV DNA could be detected by the hybrid capture assay, which utilizes a chemiluminescence substrate and is marketed as ViraType Plus by Digene Diagnostics, Beltsville, Md, U.S.A. ${ }^{(8)}$ The hybrid capture second generation (HC2) assay, approved by the U.S. Food and Drug Administration, is currently available for the detection of 13 carcinogenic HPV types, which include 16, 18, 31, 33, 35, $39,45,51,52,56,58,59$, and 68. Several important studies have used HC2, ${ }^{(9-11)}$ however, the threshold of detection is approximately 10000 copies of the virus. ${ }^{(12)}$

With the advancement of technologies such as the polymerase chain reaction (PCR), the detection limit of HPV DNA is as low as 50-100 copies/cells of the virus in a sample. ${ }^{(13)}$ However, a negative result may be related to a technical error, a sampling error, or unspecified/untested HPV genotypes, so the existence of HPV-negative cervical cancer is certainly doubtful. ${ }^{(14)}$ General (consensus) PCR primer sets, such as MY09/MY11, ${ }^{(15)} \mathrm{GP} 5+/ 6+,{ }^{(16)} \mathrm{SPF} 1 / 2,{ }^{(17)} \mathrm{CUT}$ primers, ${ }^{(18)}$ and type-specific PCR primers ${ }^{(19,20)}$ have been developed. Huang et al. created a modified set of primers (SPF1/GP6+) that amplify a 184-bp DNA fragment followed by reverse blotting of 38 types of HPV DNA with a macroarray gene chip (EasyChip ${ }^{\circledR}$ HPV Blot; King Car, Taiwan) in a single reaction. ${ }^{(21)}$ Different methods of HPV detection are shown in Table 1. The SPF1/GP6+ primer set is sensitive in detecting HPV in paraffin-embedded tissues obtained from patients with cervical cancer. ${ }^{(21)}$ The performance of HPV Blothas been shown to be comparable to that of $\mathrm{HC} 2$ in cervical swab samples as well. ${ }^{(22)}$ Discrepancies between the results of the two assays were investigated by direct sequencing and type-specific PCR. In an analysis of 354 swab samples, the concordance of HPV Blot and HC2 was $80.8 \%$, with substantial agreement between the methods. ${ }^{(22)} \mathrm{A}$ multicenter study of 468 patients compared PCR using a modified MY11/GP6+ -based HPV blot assay with L1 type-specific PCR for 20 genotypes. Hence HPV Blot was certified as an alternative diagnostic medical device in Taiwan. ${ }^{(23)}$

The list of possible causes underlying false-negative molecular diagnoses includes low viral load (below the threshold required for detection), insufficient DNA extracted from the samples, inefficient PCR amplification, or weak alkaline phosphatase substrate activity. ${ }^{(24)}$ Efforts have been made to improve the diagnostic performance of HPV DNA testing. Chao et al. demonstrated that reliable determination of HPV status is crucially dependent on the amount of input genomic DNA (for example, $25 \mathrm{ng}$ for SPF1/GP6+ PCR plus HPV Blot). ${ }^{(24)}$

\section{HPV testing for follow-up after treatment of CIN}

Lin et al. used the HC2 assay to evaluate 75 patients with grade $3 \mathrm{CIN}$ who underwent hysterectomy following conization. Those with negative results for HPV after conization were all (23/23) free of residual disease in the uterus (a 100\% negative predictive value). All those who had residual disease (27/27) had positive results for HPV at the time of hysterectomy (100\% sensitivity). ${ }^{(25)}$ This prospective study confirmed the excellent sensitivity and negative predictive value of HPV DNA testing after conization in predicting residual cervical neoplasia. ${ }^{(25)}$ Follow-up analyses of a consecutive series of 2,154 patients who had received conization revealed that HPV follow-up status was a significant predictor 
Table 1. Common HPV Typing Methods

\begin{tabular}{|c|c|c|}
\hline Method & Description & Author \\
\hline ViraType Plus & $\begin{array}{l}\text { Digene corporation, FDA approved, signal amplification to detect and quantitate } \\
\text { viral nucleic acid }\end{array}$ & 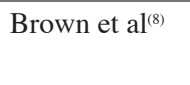 \\
\hline $\mathrm{HC} 2$ & $\begin{array}{l}\text { Digene corporation, semi-quantitative, detects } 13 \text { high-risk HPV types in a cocktail, no } \\
\text { type determination }\end{array}$ & Cavuslu et al ${ }^{(12)}$ \\
\hline MY09/11 PCR & Amplimer $450 \mathrm{bp}$, reverse line blot assay, detects 37 genotypes & Bauer et $\mathrm{al}^{(15)}$ \\
\hline $\mathrm{SPF} 1 / 2 \mathrm{PCR}$ & Amplimer 65 bp, followed by direct sequencing, sequences compared with known types & van Muyden ${ }^{(16)}$ \\
\hline GP5+/6+ or GP11/12 PCR & $\begin{array}{l}\text { Amplimer 140-150 bp, dot blot or restriction fragment length polymorphisum, detects } 11 \\
\text { genotypes }\end{array}$ & Snijders ${ }^{(17)}$ \\
\hline CUT primer PCR & Amplimer 370 bp, followed by direct sequencing, detects 69 types & Chouhy et $\mathrm{l}^{(18)}$ \\
\hline $\begin{array}{l}\text { Genpoint kit (Dako } \\
\text { cytomation, Kyoto, Japan) }\end{array}$ & $\begin{array}{l}\text { Unamplified target, in situ hybridization with biotin-labeled HPV16 probe on paraffin- } \\
\text { embedded sections }\end{array}$ & Fujii et al ${ }^{(20)}$ \\
\hline $\begin{array}{l}\text { SPF1/GP6+ PCR } \\
\text { EasyChip }{ }^{\circledast} \text { HPV Blot } \\
\text { (Kingcar, Taiwan) }\end{array}$ & Amplimer 184 bp, hybridization with (HPV Blot), detects 38 types & Huang et $\mathrm{al}^{(21)}$ \\
\hline
\end{tabular}

Abbreviations: PCR: polymerase chain reaction; HC2: hybrid capture second generation; HPV: human papillomavirus.

of residual/recurrent high-grade CIN. ${ }^{(26)}$ This result was confirmed by other prospective studies on the addition of HPV testing to conventional methods in follow-up after conization. ${ }^{(27,28)}$

HPV genotype distribution in the general population, as represented by a Taoyuan CountyChang Gung Memorial Hospital cohort

Primary screening of cervical cancer by Papanicolaou (Pap) smear or monolayer cytology provides sensitivity rates ranging from $30 \%$ to $87 \%{ }^{(29)}$ The additional value of HPV DNA testing (SPF1/GP6+ PCR plus HPV Blot) as a complementary method to the Pap smear to improve the sensitivity in detecting $\geq$ CIN2 was investigated in 10014 women (> 30 years old) who resided in Taoyuan, Taiwan who had intact uteri and no history of treatment for preinvasive or invasive cervical neoplasms. ${ }^{(30)}$ Informed consents were obtained, and cervical swab samples were collected from women at a mobile examination booth or outpatient clinics by gynecologists from Taoyuan County-Chang Gung Memorial Hospital (CGMH), local practitioners in their offices, or public health nurses at their health stations. The overall HPV prevalence in the study population was $10.8 \%$ (95\% confidence interval [CI] $10.5 \%-11.4 \%$ ). A total of 37 types of HPV were identified; the leading three were HPV52, 18, and 58. The sensitivity of the Pap smear was $81.9 \%$, which improved to $97.2 \%$ with combined Pap and HPV testing. Adding HPV testing identified an additional 11 cases and achieved a $15.3 \%$ improvement in sensitivity.

There was a significant positive correlation of HPV prevalence with older age, postmenopausal status, current use of oral contraceptives, and no history of hormone replacement therapy use. Past users of oral contraceptives and those who had never undergone Pap smears demonstrated a higher risk of abnormal Pap smears, whereas women aged 40-49 years old had a reduced risk. No specific subgroup was found to benefit most from the combined strategy. ${ }^{(30)}$ The value of adding an HPV test to the conventional Pap smear must be evaluated after longer follow-up of this population-based cohort.

Recently, a report on a community-based study of 10602 participants (age 30-65 years) from Taiwan showed that the overall HPV prevalence was $16.2 \%$ (using MY11/GP6+ PCR plus HPV Blot), and for cytologically normal participants was $13.8 \%$. The 
most common carcinogenic types were, in order, HPV52, 16, 56, and 18. ${ }^{(31)}$ The prevalence of abnormal Pap smears at baseline in this study was $3.9 \%$, including cytologically atypical squamous cells of undetermined significance (ASCUS) (1.3\%), lowgrade squamous intraepithelial lesion (LSIL) (1.1\%) and high-grade squamous intraepithelial lesions (HSIL+) (1.5\%). ${ }^{(31)}$ The prevalences of Taoyuan County- CGMH cohort of $\geqq$ HSIL and ASCUS/ LSIL were $0.45 \%$ and $1.53 \%$, respectively. The rate of abnormal Pap smears reflects the study population, which partially explains the differences between these two large studies from Taiwan. In general, hospital-based studies tend to detect higher HPV positivity among study subjects. The HPV prevalence in a hospital-based study in northern Taiwan $(\mathrm{n}=215)$ was $20.9 \%$. ${ }^{(32)}$ Similarly, in a hospital-based study performed in southern Taiwan $(n=4383)$, Lin et al. reported that the overall prevalence was $19.3 \%$, with the leading HPV types being HPV16, 52, and 58. ${ }^{(33)}$ The age-specific curves of HPV prevalence were Ushaped, and the prevalence of HPV in women $>30$ years old $(32 \%)$ was higher than that in women $>30$ years old (17.2\%). ${ }^{(33)}$ However, in the Dutch Population Based Screening Study Amsterdam trial $(n=44102)$, the prevalence of high-risk HPV decreased from $12 \%$ at age $29-33$ years to $2.4 \%$ at $59-61$ years. $^{(34)}$

\section{Three-year follow-up of HPV testing to comple- ment Pap smears in cervical screening}

Incorporating HPV testing into cervical cancer screening has been advocated. Although the specificity of the test would be decreased, an expected increase in the sensitivity of early detection of highgrade cervical neoplasms is predicted. ${ }^{(11,35)}$ The identification of a high-risk HPV infection causes anxiety in patients. Because of lack of adequate knowledge in predicting the outcome, the appropriate approach to management is unclear, except for the need for periodic follow-up care.

Several host factors, such as older age, ${ }^{(36)}$ hormone replacement therapy, ${ }^{(37)}$ concurrent other lowergenital tract infections, ${ }^{(38)}$ a generalized decrease in immune responsiveness, ${ }^{(39)}$ parity, ${ }^{(40)}$ and viral variables, such as HPV genotype, ${ }^{(36,40,41)}$ multiple HPV infections, ${ }^{(36,38)}$ and multiple HPV variants, ${ }^{(42)}$ have been reported to be associated with HPV persistence/decreased clearance.
Women $\geq 30$ years old with HPV-positive status but normal cytology and a negative colposcopy were recruited into a 3-year longitudinal follow-up study. ${ }^{(43)}$ Of the 626 eligible women, 526 (median age 47 years, range 29-75 years) were enrolled, and 412 returned at least once for follow-up. The median follow-up time of the enrolled subjects was 23 months (range 6.8-39). The 3-year cumulative total HPV clearance rate was $49.0 \%$ (95\% CI: $43.3 \%-54.7 \%$ ). The median 3-year cumulative type-specific HPV clearance rate was $50.0 \%$ (range $0 \%-100.0 \%$ ), with a median time to clearance of 12.4 months (range 6.424.5). Older age and high viral load were associated with significantly decreased total HPV clearance. After adjusting for confounding variables, the hazard ratio for developing $\geq$ CIN2 in baseline HPV-positive women was 34.0 -fold (95\% CI: 15.5-74.7) that in HPV-negative women. Therefore, careful followup is important in HPV-positive women with normal cytology. The above study is ongoing, involving an additional 3 years of periodic long-term follow-up and an expanded number of subjects to obtain a comprehensive clinical profile.

In a 5-year follow-up study of 1708 women treated at ten hospitals in seven cities around Taiwan, 108 cytology-negative and HPV-positive women and 1202 cytology- and HPV-negative women were analyzed. ${ }^{(4)}$ The cumulative incidences of high-grade CIN and cervical cancer in HPV-positive women were 5.6 and $3.7 \%$, respectively, whereas those in HPV-negative women were 0.3 and $0 \%$, respectively. HPV-positive women had a 24.9-fold higher chance of developing $\geq \mathrm{CIN} 2$ than HPV-negative subjects. ${ }^{(4)}$

To analyze women who were Pap- and HPVnegative at baseline, a nested cohort of subjects $(\mathrm{n}=$ 8825 ) from a population-based cervical cancer screening study who were followed for 3 years was investigated. ${ }^{(45)}$ The incidence of novel acquisition of HPV was 4.2 per 100 woman-years. The 3 -year cumulative total HPV acquisition rate was $11.1 \%$ (95\% CI: 8.1-14.1). Multivariate analysis revealed that an increased number of sexual partners ( $\geq 2 \mathrm{vs}$. 1) was associated with an increased risk of HPV infection (odds ratio [OR]: 5.0, 95\% CI: 2.0-12.6). Three cases of $\geq$ CIN2 were identified among active HPV-negative subjects at the 3-year follow-up. The HPV genotypes in the dysplastic tissues were revealed to be present in the baseline samples of two of these three cases after reanalysis. In the passive 
HPV-negative group, only one case progressed to CIN2, probably after HPV acquisition. It was concluded that negative Pap and HPV tests conferred an extremely low risk of developing $\geq \mathrm{CIN} 2$ within 3 years despite incident HPV infection. A screening interval of 3 years is safe and recommended. ${ }^{(4)}$

\section{HPV testing as triage for borderline or low- grade abnormal cervical cytology}

The Taiwan Cooperative Oncology Group initiated an epidemiologic HPV prevalence study of 1264 women with abnormal cervical cytology visiting gynecologic clinics of 11 major medical centers in 2005. ${ }^{(46)}$ The prevalences of HPV in the atypical squamous/glandular cells with undetermined significance (suspicious) $(\mathrm{n}=316)$ and low-grade intraepithelial lesions $(n=474)$ were $36.1 \%$ and $74.7 \%$, respectively. The main correlates of HPV prevalence were lifetime number of sex partners $\geqq 2$, vaginal douching after intercourse, vitamin supplementation, and performance of Pap smear tests. The risk for vaginal douching was augmented by the promiscuity of sex partners and smoking, whereas vitamin supplementation had some protection in reducing HPV infection. The results of this study provided data on the epidemiologic correlates of HPV in borderline and LSIL. ${ }^{(46)}$ To predict the progression of LSILs with HPV infection, Ho et al. analyzed 65 LSILs with HPV DNA types $16,18,52$, or 58 among 294 women with baseline LSILs. They found that women with LSILs whose viral loads increased between baseline and the 6-month follow-up had a $45 \%$ risk of developing HSIL (OR $=7.6,95 \% \mathrm{CI}=1.9-29.4, p$ $<0.01)$ as evaluated by real-time PCR and a $44 \%$ risk $(\mathrm{OR}=6.1,95 \% \mathrm{CI}=1.6-22.7, p<0.01)$ as evaluated by HC2. The authors concluded that evaluation of viral load changes (increased or not increased) through repeat HPV DNA testing could predict disease progression in LSIL cases with HPV types 16, 18,52 , and $58 .{ }^{(47)}$

To determine the effects of age, Lin and associates analyzed 119 women over 50 years old with ASCUS or LSIL. Those who had positive HPV infections were at increased risk for developing $\geq$ CIN2. ${ }^{(48)}$ The ASCUS-LSIL Triage Study recruited 3488 women with ASCUS and randomly assigned them to the following three groups: immediate colposcopy arm (referral to colposcopy regardless of enrollment test result), HPV triage arm (referral to colposcopy if positive for HPV), and conservative arm (referral to colposcopy if cytology was HSIL). ${ }^{(9)}$ The results showed that the cumulative diagnoses of CIN3 did not vary significantly among the three groups. The conservative strategy of repeat cytology at the HSIL threshold referred $12.3 \%$ of women to colposcopy while detecting $54.6 \%$ of cumulative CIN3. The HPV triage strategy referred $55.6 \%$ of women and detected $72.3 \%$ of cumulative cases of CIN3. By halving the number of women referred for colposcopy, HPV testing triage is considered costeffective in the United States. The situation is different in Taiwan, where immediate colposcopy is cheaper than HPV testing. However, with HPV genotype information, the decision to perform a biopsy could be different for different gynecologists performing the colposcopy.

\section{HPV genotype distribution in CIN and invasive cervical cancer in Taiwan}

In another study from Taiwan, HPV genotyping was performed on 1086 paraffin-embedded, formaldehyde-fixed CIN 2/3 specimens excised between 1999 and 2001 at CGMH. ${ }^{(49)}$ HPV DNA was detected in $91.6 \%$ of the specimens, and multiple HPV types were identified in $19.3 \%$. The most common HPV types were HPV16 (24\%), 52 (20\%), 58 $(20 \%), 33(13 \%), 31(8 \%)$, and 18 (4.6\%). The leading 6 types accounted for $87.6 \%$ of the cases, and HPV16 or 18 accounted for only $30.9 \%$. In women older than 50 years, HPV16 and 18 accounted for $21.3 \%$, and HPV52, 58 and 33 represented 55.5\%. In women younger than 50 years, HPV 16 and 18 accounted for $32.1 \%$ of cases $(p<0.0001)$, and HPV52, 58 and 33 accounted for $47.9 \%(p=0.02)$. The rates of HPV16, 18, 39, and 45 infection were significantly higher in cervical cancer than in CIN $2 / 3(n=2118)$. Comparison of HPV typing in cancer and CIN 2/3 between Taoyuan and other geographical regions in a meta-analysis is shown in Table 2. ${ }^{(49,50)}$ Interestingly, HPV16 was the most common HPV type in cervical cancer in all geographical regions in the world. Therefore, an effective vaccine against the most common HPV types could prevent a significant proportion of the cervical cancer cases that occur in Taiwan.

In a community-based cohort of 10602 participants, HPV16 was found in $48.2 \%$ of 56 cases of invasive and in situ cervical cancer. ${ }^{(31)}$ In a study of 
Table 2. Geographical Distribution of Prevalence of HPV Types in Cervical Intraepithelial Neoplasia Grades 2 and 3 and Squamous Cell Carcinoma of the Cervix

\begin{tabular}{|c|c|c|c|c|c|c|c|c|c|c|}
\hline \multirow{3}{*}{ HPV types } & \multicolumn{5}{|c|}{ Taiwan(49) } & \multicolumn{5}{|c|}{ World(50)* } \\
\hline & \multicolumn{2}{|c|}{ SCC } & \multicolumn{2}{|c|}{ CIN $2 / 3$} & \multirow{2}{*}{$\begin{array}{c}\text { Prevalence ratio } \\
\text { CC: CIN2/3 }\end{array}$} & \multicolumn{2}{|c|}{ SCC } & \multicolumn{2}{|c|}{ CIN $2 / 3$} & \multirow{2}{*}{$\begin{array}{c}\text { Prevalence ratio } \\
\text { SCC: CIN2/3 }\end{array}$} \\
\hline & $\mathrm{n}$ & $\%$ & $\mathrm{n}$ & $\%$ & & $\mathrm{n}$ & $\%$ & $\mathrm{n}$ & $\%$ & \\
\hline All & 1836 & $99.4 \mathrm{~b}$ & 995 & $91.6^{\mathrm{h}}$ & $1.09(1.07-1.11)$ & 9494 & $89.7 \mathrm{~b}$ & 7094 & $84.9 \mathrm{~h}$ & $1.06(1.05-1.07)$ \\
\hline 16 & 973 & 52.7 & 262 & $24.1^{\mathrm{i}}$ & $2.18(1.95-2.45)$ & 9494 & 55.2 & 7094 & $45.3 \mathrm{i}$ & $1.30(1.26-1.34)$ \\
\hline 58 & 325 & $17.6^{\mathrm{c}}$ & 216 & $19.9^{\mathrm{j}}$ & $0.89(0.76-1.03)$ & 6873 & $2.8 \mathrm{c}$ & 4181 & $7.0^{\mathrm{j}}$ & $0.30(0.25-0.35)$ \\
\hline 18 & 282 & $15.3^{\mathrm{d}}$ & 50 & $4.6 \mathrm{k}$ & $3.33(2.49-4.44)$ & 9402 & $12.8^{\mathrm{d}}$ & 6978 & $6.9 \mathrm{k}$ & $1.76(1.58-1.95)$ \\
\hline 33 & 171 & $9.3^{e}$ & 142 & 13.11 & $0.71(0.57-0.87)$ & 8803 & $3.7^{\mathrm{e}}$ & 6418 & 7.31 & $0.52(0.45-0.60)$ \\
\hline 52 & 136 & $7.4 \mathrm{f}$ & 220 & $20.3^{\mathrm{m}}$ & $0.36(0.30-0.44)$ & 6431 & $2.9 \mathrm{f}$ & 3945 & $5.1 \mathrm{~m}$ & $0.44(0.36-0.54)$ \\
\hline 31 & 44 & $2.4^{\mathrm{g}}$ & 81 & 7.5 & $0.32(0.22-0.46)$ & 7565 & $3.8 \mathrm{~g}$ & 6282 & 8.6 & $0.53(0.45-0.61)$ \\
\hline
\end{tabular}

Abbreviations: HPV: human papillomavirus; CIN2/3: cervical intraepithelial neoplasia grades 2 and 3; SCC: squamous cell carcinoma; *: Data in the meta-analysis (50) gained from Africa, Asia, Europe, North America, Oceania, and South /Central America.

Bold indicates significance between Taiwan and the world in SCC or CIN2/3.; $p$-values: $\mathrm{b}<0.001, \mathrm{c}<0.001, \mathrm{~d}<0.0037, \mathrm{e}<0.001, \mathrm{f}<$ $0.001, \mathrm{~g}<0.0034, \mathrm{~h}<0.001, \mathrm{i}<0.001, \mathrm{j}<0.001, \mathrm{k}<0.0045,1<0.001, \mathrm{~m}<0.001$.

40 patients with cervical cancer in Hualien, the HPV16 and 18 genotypes were found in $70 \%$ of the specimens analyzed. ${ }^{(51)}$ HPV 16 was detected in $68 \%$ of 37 patients with squamous cell carcinoma, while HPV18 was detected in $5.4 \%$.

\section{Prognostic value of HPV genotype in cervical cancer}

In the early 1990s, National Taiwan University Hospital reported an HPV positive rate of $79 \%$ in 433 cervical cancer samples of stage I-II fresh-frozen tissues from radical hysterectomies. ${ }^{(52)}$ HPV 16, 18 , 31 , and 33 were detected with MY9/MY11 probes. The authors found that pelvic lymph node metastases were significantly more prevalent in HPV-positive (24.3\%) than HPV-negative (11\%) women with stage I disease. Furthermore, the incidence of positive lymph nodes was significantly associated with squamous cell carcinoma $(p<0.01)$, but not with adenocarcinoma. Interestingly, the authors did not find any HPV genotype that exhibited prognostic significance. However, researchers at Tri-Service General Hospital analyzed 94 cases of stage I-IV fresh-frozen specimens and found that HPV58-related types (types 58, 33, and 52) were prevalent in the older age group ( $>52$ years) and predicted a favorable outcome. ${ }^{(53)}$ However, neither the status of lymph node metastasis not tumor grade correlated with HPV typing. ${ }^{(53)}$
In a large series reported by CGMH, 2118 stage I-IV paraffin-embedded archival tissues collected between 1993 and 2001 were analyzed. ${ }^{(54)}$ HPV was found in $96.6 \%$ of patients, with $18 \%$ having multiple infections. HPV16 was noted in $50 \%$ of the HPVpositive cases, followed by HPV18, 58, 33, and 52 . Type 58-related HPVs $(33,52$, or $58 ; 30.3 \%)$ were more prevalent in older patients, those with stage III and IV cancer, and those who had received radiation or concurrent chemoradiation. The 1067 patients with stage I-IIA cancer who underwent radical hysterectomy were further analyzed for prognostic outcome. ${ }^{(55)}$ Bootstrap resampling using $\mathrm{R}$ software (http://www.r-project.org) was randomly performed to construct new data sets followed by Cox regression analysis, which was repeated 1000 times; the counts of selection considered to be significant for each variable were recorded. The median follow-up of the surviving patients was 77 months.

Outcome-predicting models were constructed using seven significant covariates for either overall survival (OS) or recurrence-free survival (RFS). The prognostic score was 0 for FIGO stage I and 1 for stage II; 0 for depth of stromal invasion less than one third and 1 for stromal invasion greater than or equal to one third; 0 for no lymph node metastasis and 1 for lymph node metastasis; 0 for no parametrial extension and 1 for the presence of parametrial extension; 0 for differentiation of grade 1 and 1 for 
grade 2 or 3; 0 for HPV 18 negativity and 1 for HPV 18 positivity; 0 for age $<45$ years and 1 for age $<45$ years. The probability of dying was highest in the high-risk group (prognostic score $=4$ to 7), followed by the intermediate-risk group (prognostic score $=3$ ), and the low-risk group (prognostic score $=0$ to 2). The five-year OS rates of the high-, intermediate-, and low-risk groups were 97.4\%, 87.6\%, and $77.9 \%$, respectively. The five-year RFS rates of the high-, intermediate-, and low-risk groups were $95.9 \%, 86.7 \%$, and $72.7 \%$, respectively. The predicting models for death and relapse in early-stage cervical cancer could be useful for counseling patients before treatment and stratifying study subjects in future clinical trials. ${ }^{(54)}$

In another cohort of 1100 cervical cancer patients treated by primary radiotherapy, the leading types were the alpha-7 and -9 species. ${ }^{(56)}$ The highrisk group consisted of patients with HPV infection or those infected with the alpha-7 species only. Patients coinfected with the alpha-7 and alpha-9 species belonged to the medium-risk group, and the others were included in the low-risk group.

\section{Methylation in the carcinogenesis of cervical cancer}

In addition to HPV testing, DNA methylation has been investigated in the context of CIN and cervical cancer. ${ }^{(57-59)}$ Investigating the methylation status of $\mathrm{CpG}$ dinucleotides found within the long control region (LCR), Ding et al. reported that methylation of the LCR of HPV16 is strongly associated with the severity of the cervical neoplasm. ${ }^{(59)}$ Among cervical squamous cell carcinoma specimens, $50 \%$ were found to be methylated, whereas only $5 \%$ were methylated in LSIL. ${ }^{(59)}$ Lai et al. demonstrated that six genes (SOX1, PAX1, LMX1A, NKX6-1, WT1 and ONECUT1) were differentially expressed using a $\mathrm{CpG}$ island (CGI) microarray containing 8,640 CGI tags; this finding was further validated in cervical cancer tissues. The parallel testing of HPV and PAX1 methylation in 22 cervical swabs generated improved sensitivity compared with HPV testing alone ( $80 \%$ vs. $66 \%$, respectively) without compromising specificity (63\% vs. $64 \%$, respectively) for HSIL/SCC. When testing the PAX1 methylation marker alone, the specificity for HSIL/SCC was 99\%. ${ }^{(58)}$ In ASCUS, the odds ratios (95\% CI) for CIN 3 or more severe neoplasms in women who tested positive for methylation of three novel methylationsilenced genes (PAX1,WT1, and PCDH1O) were 26.4 (9.0-77.3), 18.1 (6.9-47.2), and 10.3 (4.1-25.9), respectively. ${ }^{(57)}$ In triage for ASCUS, each methylation test resulted in fewer colposcopy referrals and lower false-positive rates but higher false-negative rates than the HPV tests. ${ }^{(57)}$ The potential use of DNA methylation as a marker for complementing cervical cancer detection warrants studies with larger sample sizes.

\section{HPV vaccines}

HPV vaccines are divided into prophylactic and therapeutic vaccines. The prophylactic vaccines are commercially available as Gardasil ${ }^{\oplus}$ (HPV6, 11, 16, and 18) and Cervarix ${ }^{\circledast}$ (HPV16 and 18). The impact of a prophylactic vaccine on the incidence of cervical neoplasms can only be observed over the course of decades. ${ }^{(60-62)} \mathrm{A}$ decrease in the incidence of high grade cervical abnormalities within 3 years after the implementation of a population-wide HPV vaccination programme in Australia has been reported. ${ }^{(63)}$

An effective therapeutic vaccine is still urgently needed because a prophylactic vaccine does not impact HPV clearance rates of existing infections. ${ }^{(64)}$ Currently, a significant number of patients have HPV-related lesions that need to be abolished. Therapeutic vaccines mainly require the generation of $\mathrm{T}$ cell-mediated immunity and include live vectorbased, peptide- or protein-based, nucleic acid-based, and cell-based vaccines that target the HPV E6 and/or E7 antigens. ${ }^{(65)}$ DNA-based vaccines are stable, easy to produce and may be repeatedly administered. However, DNA-based therapeutic vaccines are limited in their ability to amplify and spread in vivo. Given that dendritic cells are key players in the generation of antigen-specific immune responses, strategies to modify the properties of DNA-transfected dendritic cells are being developed. ${ }^{(64)}$

Methods to enhance DNA vaccines include (1) encoding IL-2 linked to the HPV-16 E7 antigen or pretreatment with cisplatin to generate enhanced E7specific cytotoxic T lymphocytes; ${ }^{(66,67)}$ (2) improving antigen expression in dendritic cells by developing a codon-optimized HPV-16 E6 DNA vaccine (pNGVL4a-E6/opt);(68) and (3) linking HPV-16 E7 to endoplasmic reticulum chaperone molecules (ER-60, tapasin, and calnexin) ${ }^{(69)}$ to generate E7-specific $\mathrm{T}$ cell-mediated immune responses and antitumor 
effects in vaccinated mice. This led to a more potent DNA vaccine when tested in vaccinated mice compared to untreated mice. CD4 (+) T cells are also known to exert long-term antitumor effects. CD4 (+) $\mathrm{T}$ cells were shown to assist in the generation of E7specific CD8 (+) T cell immune responses in mice vaccinated with SINrep5-E7/HSP70 and boosted with vac-E7/HSP70. ${ }^{(66)}$

Several therapeutic HPV DNA vaccine trials have been completed. ${ }^{(64)}$ For instance, a microencapsulated DNA vaccine encoding HPV-16 and -18 E6and E7-derived epitopes, termed ZYC-101a (MGI Pharma), was tested in a multicenter, double-blind, randomized, placebo-controlled trial. The results were significant in a group younger than 25 years old in resolving CIN2/3 lesions compared with patients receiving a placebo. ${ }^{(64)}$ The therapeutic HPV vaccine is foreseen as a significant approach that could be combined with existing modes of therapy, such as chemotherapy or radiation.

\section{Future directions}

Epidemiological studies have shown that HPV is necessary, if not sufficient, to cause virtually $100 \%$ of cervical cancers. The question of whether HPVnegative cervical cancer exists warrants further investigation. Other pressing issues that warrant further research include the following; (1) In addition to methods such as HPV Blot with an L1 consensus primer, E6- and E7-type specific PCR, real-time quantitative PCR, and in situ hybridization that have been employed to improve HPV detection in these specimens, the next generation of sequencing technologies may allow resequencing the entire human genome to identify the binding site(s) for HPV. (2) The prevalence of high-risk HPV in vulvar, penile, and anal cancer is worthy of investigation. (3) The impact of the introduction of prophylactic HPV vaccines on the type distribution and incidence of cervical cancer and the cost-effectiveness need to be established. (4) In combination with the currently available treatment modalities, a therapeutic HPV vaccine is anticipated to play an important role in treating HPV-related diseases.

\section{Acknowledgements}

This work was supported by grants from the National Science Council-Taiwan (NSC94-2314-B182-011 and NSC97-2314-B-182-013-MY3), Chang
Gung Medical Foundation (CMRPG371152, CMRPG380731 and CMRPG391451), and the Department of Health-Taiwan (DOH99-TD-B-111005 and DOH100-TD-C-111-005). The authors are grateful to the Bureau of Health Promotion, Department of Health, Taiwan, for providing the national registry data on Pap smears and histological findings among study participants.

\section{REFERENCES}

1. Ferlay J, Shin HR, Bray F, Forman D, Mathers C, Parkin DM. Estimates of worldwide burden of cancer in 2008: GLOBOCAN 2008. Int J Cancer 2010;127:2893-917.

2. zur Hausen H, Meinhof W, Scheiber W, Bornkamm GW. Attempts to detect virus-secific DNA in human tumors. I. Nucleic acid hybridizations with complementary RNA of human wart virus. Int J Cancer 1974;13:650-6.

3. zur Hausen H. Papillomaviruses causing cancer: evasion from host-cell control in early events in carcinogenesis. J Natl Cancer Inst 2000;92:690-8.

4. Munoz N, Bosch FX, de Sanjose S, Herrero R, Castellsague X, Shah KV, Snijders PJ, Meijer CJ. Epidemiologic classification of human papillomavirus types associated with cervical cancer. N Engl J Med 2003;348:518-27.

5. de Villiers EM, Fauquet C, Broker TR, Bernard HU, zur Hausen H. Classification of papillomaviruses. Virology 2004;324:17-27.

6. Parkin DM, Louie KS, Clifford G. Burden and trends of type-specific human papillomavirus infections and related diseases in the Asia Pacific region. Vaccine 2008;26 Suppl 12:M1-16.

7. Department of Health, the Executive Yuan. Cancer registration annual report in Taiwan. Taipei: Taiwan, 2007.

8. Brown DR, Bryan JT, Cramer H, Fife KH. Analysis of human papillomavirus types in exophytic condylomata acuminata by hybrid capture and Southern blot techniques. J Clin Microbiol 1993;31:2667-73.

9. ASCUS-LSIL Traige Study (ALTS) Group. Results of a randomized trial on the management of cytology interpretations of atypical squamous cells of undetermined significance. Am J Obstet Gynecol 2003;188:1383-92.

10. Ronco G, Giorgi-Rossi P, Carozzi F, Confortini M, Dalla Palma P, Del Mistro A, Gillio-Tos A, Minucci D, Naldoni C, Rizzolo R, Schincaglia P, Volante R, Zappa M, Zorzi M, Cuzick J, Segnan N. Results at recruitment from a randomized controlled trial comparing human papillomavirus testing alone with conventional cytology as the primary cervical cancer screening test. J Natl Cancer Inst 2008;100:492-501.

11. Mayrand MH, Duarte-Franco E, Rodrigues I, Walter SD, Hanley J, Ferenczy A, Ratnam S, Coutlee F, Franco EL. 
Human papillomavirus DNA versus Papanicolaou screening tests for cervical cancer. N Engl J Med 2007;357: 1579-88.

12. Cavuslu S, Mant C, Starkey WG, Bible JM, Biswas C, Kell B, Rice P, Best JM, Cason J. Analytic sensitivities of hybrid-capture, consensus and type-specific polymerase chain reactions for the detection of human papillomavirus type 16 DNA. J Med Virol 1996;49:319-24.

13. Shibata D, Martin WJ, Arnheim N. Analysis of DNA sequences in forty-year-old paraffin-embedded thin-tissue sections: a bridge between molecular biology and classical histology. Cancer Res 1988;48:4564-6.

14. Walboomers JM, Jacobs MV, Manos MM, Bosch FX, Kummer JA, Shah KV, Snijders PJ, Peto J, Meijer CJ, Munoz N. Human papillomavirus is a necessary cause of invasive cervical cancer worldwide. J Pathol 1999;189: $12-9$.

15. Bauer HM, Ting Y, Greer CE, Chambers JC, Tashiro CJ, Chimera J, Reingold A, Manos MM. Genital human papillomavirus infection in female university students as determined by a PCR-based method. JAMA 1991;265: 472-7.

16. van Muyden RC, ter Harmsel BW, Smedts FM, Hermans J, Kuijpers JC, Raikhlin NT, Petrov S, Lebedev A, Ramaekers FC, Trimbos JB, Kleter B, Quint WG. Detection and typing of human papillomavirus in cervical carcinomas in Russian women: a prognostic study. Cancer 1999;85:2011-6.

17. Snijders PJ, van den Brule AJ, Schrijnemakers HF, Snow G, Meijer CJ, Walboomers JM. The use of general primers in the polymerase chain reaction permits the detection of a broad spectrum of human papillomavirus genotypes. J Gen Virol 1990;71 Pt 1:173-81.

18. Chouhy D, Gorosito M, Sanchez A, Serra EC, Bergero A, Fernandez Bussy R, Giri AA. New generic primer system targeting mucosal/genital and cutaneous human papillomaviruses leads to the characterization of HPV 115, a novel Beta-papillomavirus species 3. Virology 2010;397: 205-16.

19. Baay MF, Quint WG, Koudstaal J, Hollema H, Duk JM, Burger MP, Stolz E, Herbrink P. Comprehensive study of several general and type-specific primer pairs for detection of human papillomavirus DNA by PCR in paraffinembedded cervical carcinomas. J Clin Microbiol 1996;34: 745-7.

20. Fujii T, Masumoto N, Saito M, Hirao N, Niimi S, Mukai M, Ono A, Hayashi S, Kubushiro K, Sakai E, Tsukazaki $\mathrm{K}$, Nozawa S. Comparison between in situ hybridization and real-time PCR technique as a means of detecting the integrated form of human papillomavirus 16 in cervical neoplasia. Diagn Mol Pathol 2005;14:103-8.

21. Huang HJ, Huang SL, Lin CY, Lin RW, Chao FY, Chen MY, Chang TC, Hsueh S, Hsu KH, Lai CH. Human papillomavirus genotyping by a polymerase chain reactionbased genechip method in cervical carcinoma treated with neoadjuvant chemotherapy plus radical surgery. Int J Gynecol Cancer 2004;14:639-49.

22. Huang SL, Chao A, Hsueh S, Chao FY, Huang CC, Yang JE, Lin CY, Yan CC, Chou HH, Huang KG, Huang HJ, Wu TI, Tseng MJ, Qiu JT, Lin CT, Chang TC, Lai CH. Comparison between the Hybrid Capture II Test and a SPF1/GP6+ PCR-based assay for detection of human papillomavirus DNA in cervical swab samples. J Clin Microbiol 2006;44:1733-9.

23. Lin CY, Chao A, Yang YC, Chou HH, Ho CM, Lin RW, Chang TC, Chiou JY, Chao FY, Wang KL, Chien TY, Hsueh S, Huang CC, Chen CJ, Lai CH. Human papillomavirus typing with a polymerase chain reaction-based genotyping array compared with type-specific PCR. J Clin Virol 2008;42:361-7.

24. Chao FY, Chao A, Huang CC, Hsueh S, Yang JE, Huang HJ, Wang LC, Lin CT, Chou HH, Lai CH. Defining detection threshold and improving analytical proficiency of HPV testing in clinical specimens. Gynecol Oncol 2010;117:302-7.

25. Lin CT, Tseng CJ, Lai CH, Hsueh S, Huang KG, Huang HJ, Chao A. Value of human papillomavirus deoxyribonucleic acid testing after conization in the prediction of residual disease in the subsequent hysterectomy specimen. Am J Obstet Gynecol 2001;184:940-5.

26. Chao A, Lin CT, Hsueh S, Chou HH, Chang TC, Chen MY, Lai CH. Usefulness of human papillomavirus testing in the follow-up of patients with high-grade cervical intraepithelial neoplasia after conization. Am J Obstet Gynecol 2004;190:1046-51.

27. Nobbenhuis MA, Meijer CJ, van den Brule AJ, Rozendaal L, Voorhorst FJ, Risse EK, Verheijen RH, Helmerhorst TJ. Addition of high-risk HPV testing improves the current guidelines on follow-up after treatment for cervical intraepithelial neoplasia. Br J Cancer 2001;84:796-801.

28. Bekkers RL, Melchers WJ, Bakkers JM, Hanselaar AG, Quint WG, Boonstra H, Massuger LF. The role of genotype-specific human papillomavirus detection in diagnosing residual cervical intraepithelial neoplasia. Int J Cancer 2002;102:148-51.

29. Nanda K, McCrory DC, Myers ER, Bastian LA, Hasselblad V, Hickey JD, Matchar DB. Accuracy of the Papanicolaou test in screening for and follow-up of cervical cytologic abnormalities: a systematic review. Ann Intern Med 2000;132:810-9.

30. Chao A, Hsu KH, Lai CH, Huang HJ, Hsueh S, Lin SR, Jung SM, Chao FY, Huang SL, Huang CC, Yang JE, Chang TC. Cervical cancer screening program integrating Pap smear and HPV DNA testing: A population-based study. Int J Cancer 2008;122:2835-41.

31. Chen HC, You SL, Hsieh CY, Schiffman M, Lin CY, Pan MH, Chou YC, Liaw KL, Hsing AW, Chen CJ. Prevalence of genotype-specific human papillomavirus infection and cervical neoplasia in Taiwan: a communitybased survey of 10,602 women. Int J Cancer 2011;128: 
1192-203.

32. Tsao KC, Huang CG, Kuo YB, Chang TC, Sun CF, Chang CA, Yang SL, Chan EC. Prevalence of human papillomavirus genotypes in northern Taiwanese women. J Med Virol 2010;82:1739-45.

33. Lin H, Ma YY, Moh JS, Ou YC, Shen SY, ChangChien CC. High prevalence of genital human papillomavirus type 52 and 58 infection in women attending gynecologic practitioners in South Taiwan. Gynecol Oncol 2006;101: 40-5.

34. Bulkmans NW, Rozendaal L, Snijders PJ, Voorhorst FJ, Boeke AJ, Zandwijken GR, van Kemenade FJ, Verheijen $\mathrm{RH}$, v Groningen K, Boon ME, Keuning HJ, van Ballegooijen M, van den Brule AJ, Meijer CJ. POBASCAM, a population-based randomized controlled trial for implementation of high-risk HPV testing in cervical screening: design, methods and baseline data of 44,102 women. Int J Cancer 2004;110:94-101.

35. Cuzick J, Szarewski A, Terry G, Ho L, Hanby A, Maddox P, Anderson M, Kocjan G, Steele ST, Guillebaud J. Human papillomavirus testing in primary cervical screening. Lancet 1995;345:1533-6.

36. Ho GY, Bierman R, Beardsley L, Chang CJ, Burk RD. Natural history of cervicovaginal papillomavirus infection in young women. N Engl J Med 1998;338:423-8.

37. Smith EM, Ritchie JM, Levy BT, Zhang W, Wang D, Haugen TH, Turek LP. Prevalence and persistence of human papillomavirus in postmenopausal age women. Cancer Detect Prev 2003;27:472-80.

38. Samoff E, Koumans EH, Markowitz LE, Sternberg M, Sawyer MK, Swan D, Papp JR, Black CM, Unger ER. Association of Chlamydia trachomatis with persistence of high-risk types of human papillomavirus in a cohort of female adolescents. Am J Epidemiol 2005;162:668-75.

39. Garcia-Pineres AJ, Hildesheim A, Herrero R, Trivett M, Williams M, Atmetlla I, Ramirez M, Villegas M, Schiffman M, Rodriguez AC, Burk RD, Hildesheim M, Freer E, Bonilla J, Bratti C, Berzofsky JA, Pinto LA. Persistent human papillomavirus infection is associated with a generalized decrease in immune responsiveness in older women. Cancer Res 2006;66:11070-6.

40. Molano M, Van den Brule A, Plummer M, Weiderpass E, Posso H, Arslan A, Meijer CJ, Munoz N, Franceschi S. Determinants of clearance of human papillomavirus infections in Colombian women with normal cytology: a population-based, 5-year follow-up study. Am J Epidemiol 2003;158:486-94.

41. Bulkmans NW, Berkhof J, Bulk S, Bleeker MC, van Kemenade FJ, Rozendaal L, Snijders PJ, Meijer CJ. Highrisk HPV type-specific clearance rates in cervical screening. Br J Cancer 2007;96:1419-24.

42. Aho J, Hankins C, Tremblay C, Forest P, Pourreaux K, Rouah F, Coutlee F. Genomic polymorphism of human papillomavirus type 52 predisposes toward persistent infection in sexually active women. J Infect Dis
2004;190:46-52.

43. Lai CH, Chao A, Chang CJ, Chao FY, Huang HJ, Hsueh S, Lin CT, Cheng HH, Huang CC, Yang JE, Wu TI, Chou $\mathrm{HH}$, Chang TC. Host and viral factors in relation to clearance of human papillomavirus infection: A cohort study in Taiwan. Int J Cancer 2008;123:1685-92.

44. Huang YK, You SL, Yuan CC, Ke YM, Cao JM, Liao CY, Wu CH, Hsu CS, Huang KF, Lu CH, Twu NF, Chu TY. Long-term outcomes of high-risk human papillomavirus infection support a long interval of cervical cancer screening. Br J Cancer 2008;98:863-9.

45. Chao A, Chang CJ, Lai CH, Chao FY, Hsu YH, Chou HH, Huang HJ, Jung SM, Lin CT, Cheng HH, Huang CC, Yang JE, Chang TC. Incidence and outcome of acquisition of human papillomavirus infection in women with normal cytology--a population-based cohort study from Taiwan. Int J Cancer 2010;126:191-8.

46. Sun CA, Hsiung CA, Lai CH, Chen CA, Chou CY, Ho CM, Twu NF, Feng WL, Chuang MH, Hsieh CY, Chu TY. Epidemiologic correlates of cervical human papillomavirus prevalence in women with abnormal Pap smear tests: a Taiwan Cooperative Oncology Group (TCOG) study. J Med Virol 2005;77:273-81.

47. Ho CM, Cheng WF, Chu TY, Chen CA, Chuang MH, Chang SF, Hsieh CY. Human papillomaviral load changes in low-grade squamous intraepithelial lesions of the uterine cervix. Br J Cancer 2006;95:1384-9.

48. Lin CT, Tseng CJ, Lai CH, Hsueh S, Huang HJ, Law KS. High-risk HPV DNA detection by Hybrid Capture II. An adjunctive test for mildly abnormal cytologic smears in women $>$ or $=50$ years of age. J Reprod Med 2000;45: 345-50.

49. Chao A, Jao MS, Huang CC, Huang HJ, Cheng HH, Yang JE, Hsueh S, Chen TC, Qiu JT, Lin CT, Fu CJ, Chou HH, Lai CH. Human papillomavirus genotype in cervical intraepithelial neoplasia grades 2 and 3 of Taiwanese women. Int J Cancer 2011;128:653-9.

50. Smith JS, Lindsay L, Hoots B, Keys J, Franceschi S, Winer R, Clifford GM. Human papillomavirus type distribution in invasive cervical cancer and high-grade cervical lesions: a meta-analysis update. Int J Cancer 2007;121: 621-32.

51. Hsu YH, Wei TC, Horng IJ, Jan WC, Su IJ. Prevalence of human papilloma virus 16 or 18 in cervical cancer in Hualien, eastern Taiwan. Kaohsiung J Med Sci 1997;13: 315-9.

52. Chen TM, Chen CA, Wu CC, Huang SC, Chang CF, Hsieh CY. The genotypes and prognostic significance of human papillomaviruses in cervical cancer. Int $\mathrm{J}$ Cancer 1994;57:181-4.

53. Lai HC, Sun CA, Yu MH, Chen HJ, Liu HS, Chu TY. Favorable clinical outcome of cervical cancers infected with human papilloma virus type 58 and related types. Int J Cancer 1999;84:553-7.

54. Lai CH, Huang HJ, Hsueh S, Chao A, Lin CT, Huang SL, 
Chao FY, Qiu JT, Hong JH, Chou HH, Chang TC, Chang CJ. Human papillomavirus genotype in cervical cancer: A population-based study. Int J Cancer 2007;120:19992006.

55. Lai CH, Chang CJ, Huang HJ, Hsueh S, Chao A, Yang JE, Lin CT, Huang SL, Hong JH, Chou HH, Wu TI, Huang KG, Wang CC, Chang TC. Role of human papillomavirus genotype in prognosis of early-stage cervical cancer undergoing primary surgery. J Clin Oncol 2007;25: 3628-34.

56. Wang CC, Lai CH, Huang HJ, Chao A, Chang CJ, Chang TC, Chou HH, Hong JH. Clinical effect of human papillomavirus genotypes in patients with cervical cancer undergoing primary radiotherapy. Int J Radiat Oncol Biol Phys 2010;78:1111-20.

57. Lin CJ, Lai HC, Wang KH, Hsiung CA, Liu HW, Ding DC, Hsieh CY, Chu TY. Testing for methylated PCDH10 or WT1 is superior to the HPV test in detecting severe neoplasms (CIN3 or greater) in the triage of ASC-US smear results. Am J Obstet Gynecol 2011;204:21 e1-7.

58. Lai HC, Lin YW, Huang TH, Yan P, Huang RL, Wang HC, Liu J, Chan MW, Chu TY, Sun CA, Chang CC, Yu $\mathrm{MH}$. Identification of novel DNA methylation markers in cervical cancer. Int J Cancer 2008;123:161-7.

59. Ding DC, Chiang MH, Lai HC, Hsiung CA, Hsieh CY, Chu TY. Methylation of the long control region of HPV16 is related to the severity of cervical neoplasia. Eur J Obstet Gynecol Reprod Biol 2009;147:215-20.

60. Solomon D, Castle P, Hildesheim A, Katki HA, Schiffman M, Wacholder S. HPV vaccination in women aged 24-45 years. Lancet 2009;374:1239.

61. Michels KB, zur Hausen H. HPV vaccine for all. Lancet
2009;374:268-70.

62. Roden R, Wu TC. How will HPV vaccines affect cervical cancer? Nat Rev Cancer 2006;6:753-63.

63. Brotherton JM, Fridman M, May CL, Chappell G, Saville AM, Gertig DM. Early effect of the HPV vaccination programme on cervical abnormalities in Victoria, Australia: an ecological study. Lancet 2011;377:2085-92.

64. Monie A, Tsen SW, Hung CF, Wu TC. Therapeutic HPV DNA vaccines. Expert Rev Vaccines 2009;8:1221-35.

65. Su JH, Wu A, Scotney E, Ma B, Monie A, Hung CF, Wu TC. Immunotherapy for cervical cancer: Research status and clinical potential. BioDrugs 2010;24:109-29.

66. Tseng CW, Hung CF, Alvarez RD, Trimble C, Huh WK, Kim D, Chuang CM, Lin CT, Tsai YC, He L, Monie A, Wu TC. Pretreatment with cisplatin enhances E7-specific CD8+ T-Cell-mediated antitumor immunity induced by DNA vaccination. Clin Cancer Res 2008;14:3185-92.

67. Lin CT, Tsai YC, He L, Yeh CN, Chang TC, Soong YK, Monie A, Hung CF, Lai CH. DNA vaccines encoding IL2 linked to HPV-16 E7 antigen generate enhanced E7-specific CTL responses and antitumor activity. Immunol Lett 2007;114:86-93.

68. Lin CT, Tsai YC, He L, Calizo R, Chou HH, Chang TC, Soong YK, Hung CF, Lai CH. A DNA vaccine encoding a codon-optimized human papillomavirus type 16 E6 gene enhances CTL response and anti-tumor activity. J Biomed Sci 2006; 13:481-8.

69. Lin CT, Chang TC, Chao A, Dzeng E, Soong YK, Hung $\mathrm{CF}$, Lai $\mathrm{CH}$. Enhancement of DNA vaccine potency through linkage of antigen gene to ER chaperone molecules, ER-60, tapasin, and calnexin. J Biomed Sci 2005;12:279-87. 


\title{
人類乳突狀病毒在台灣的子宮頸癌預防，診斷和預後之研究
}

\author{
趙安琪 黄慧君 賴瓊慧
}

子宫形癌的發病率在全世界婦女癌症排名第三, 而死亡率排名第四。流行病學研究顯 示, 人類乳突狀病毒 (HPV) 是造成近 100\% 的子宫頙癌的主要因素。HPV 檢測在初级篩檢子 宫頸腫瘤的用途是被肯定。HPV 基因分型檢測用於邊緣或低度子宫頚細胞學異常, 治療後續 子宫頸皮内贅瘤病變 $(\mathrm{CIN})$ 及評估子宫頚癌預後及擬定治療計劃有潛在的價值。長庚醫院的研 究已奠定了子宫頸癌的 HPV 基因型在台灣的分佈及獨立預後價值的確認。使用 HPV 檢測在 預防和處理子宫頸腫瘤的決策依個別國家的醫療衛生基礎設施而有不同的成本效益。在台灣 人口的盛行率和 HPV 基因型的分佈以及縱向追蹤研究提供堅強的支持台灣將 HPV 檢測納入 與子宫頸細胞學做子宫頸腫瘤篩檢; 以及未來在 HPV 預防性疫苗實施前、後 HPV 流行病學 的比較。在文中也會討論未來的 HPV 研究方向。(長庚醫誌 2012;35:297-308)

關鍵詞：子宫頸腫瘤, 人類乳突狀病毒, 癌症笠檢, 預後 